\title{
Effect of Method of Crop Establishment and Nutrient Management in Barnyard Millet under Sodic Soil Condition
}

\author{
S. Anandha Krishnaveni* \\ Anbil Dharmalingam Agricultural College and Research Institute, Navalurkuttapattu, \\ Tiruchirapalli - 620 027, India \\ *Corresponding author
}

\section{A B S T R A C T}

\begin{tabular}{|l|}
\hline K e y w o r d s \\
$\begin{array}{l}\text { Crop establishment, } \\
\text { nutrient requirement, } \\
\text { barnyard millet, sodic soil }\end{array}$ \\
\hline Article Info \\
\hline $\begin{array}{l}\text { Accepted: } \\
\text { 04 November } 2018 \\
\text { Available Online: } \\
\text { 10 December } 2018\end{array}$ \\
\hline
\end{tabular}

Keywords

Crop establishment, barnyard millet, sodic soil
An experiment was conducted with an objective to find out the effect of different methods of crop establishment and to optimize the nutrient requirement for barnyard millet (Kudiraivali) under sodic soil condition using the short duration high yielding variety Co $(\mathrm{KV})_{2}$ during kharif season of 2016 at Anbil Dharma lingam Agricultural College and Research Institute. The experiment was carried out in FRBD comprising two factors viz., crop establishment techniques like line sowing at $25 \times 10 \mathrm{~cm}\left(\mathrm{E}_{1}\right)$ and $35 \times 10 \mathrm{~cm}\left(\mathrm{E}_{2}\right)$ and transplanting at $25 \times 10 \mathrm{~cm}\left(\mathrm{E}_{3}\right)$ and $35 \times 10 \mathrm{~cm}\left(\mathrm{E}_{4}\right)$ and nutrient management practices like $\mathrm{N}_{1}$ at $75 \%, \mathrm{~N}_{2} 100 \%$ and $\mathrm{N}_{3} 125 \%$ recommended dose of fertilizers. The experiment was replicated thrice. Totally twelve treatment combinations were analyzed. Results revealed that transplanting at $35 \times 10 \mathrm{~cm}$ with $125 \%$ RDF recorded higher grain yield of $980 \mathrm{~kg} / \mathrm{ha}$ with increased growth parameters like plant height, number of tillers and yield attributes viz., number of panicles, length of panicle and weight of the panicle.

\section{Introduction}

In recent years, there has been increasing recognition of the importance of millets as a substitute for major cereal crops. Millets have the potentiality of contributing to increased food production both in developing and developed countries Sahu (1965).

Barnyard millet or Kudiraivali (Echinochloa frumentacea) is native of Eurasia. In India it is an important dry land crop and cultivated over a wide array of environmental conditions even under poor soil conditions. It has the special feature of drought resistance and can withstand water logging up to two weeks. It has field duration of 70-90 days. Due to its quick growth, it can be grown as a short-term catch crop. It is used as reclamation crops on land that is too saline for rice. It is the very quickest crop among all millets. It is equally important as a grain and fodder crop. Thus it deserves a greater importance than other millets. However, in reality the potentiality of this crop is not fully exploited.

One of the major reasons for low productivity of crops grown in salt-affected soil is the salt toxicity and poor soil properties (Gao et al., 2008). In India, 3.79 million ha and 0.35 million ha in Tamil Nadu have been affected by sodicity which affects productivity of the 
land directly. Soil sodicity is characterized by high $\mathrm{pH}$, high water soluble and exchangeable sodium and low biological activity. As a result, these soils exhibit poor physical properties often leading to low water conductivity at the surface and transmission within the profile besides, being deficient in many essential nutrients (Ghafoor et al., 2008).

The lower crop productivity is mainly due to poor crop management practices such as inadequate planting density and nutrition, high weed infestation, incidence of disease and insect pests. Optimum population level is the one, which provides the plant with the best environment to express its capacity fully under the given conditions. Intra and inter row spacing is one of the important components of systematic cultivation and manipulation, that could enhance productivity of this important crop. Due to proper spacing plant can gain sufficient sunlight, water and nutrition from soil, which can influence healthy yield and yield attributesn. Therefore, there is a need to understand the relationship between plant density and nutrient requirement with yield. Hence, an experiment was carried out with an objectives to find out the suitable crop establishment technique and to optimize the nutrient requirement for barnyard millet (kudiraivali) under sodic soil condition.

\section{Materials and Methods}

A field experiment was conducted at Anbil Dharmalingam Agricultural College and Research Institute with an objective to find out the suitable crop establishment method and to optimize the nutrient requirement for barnyard millet (Kudiraivali) under sodic soil condition using the short duration high yielding variety Co $(\mathrm{KV})_{2}$ during kharif season of 2016.The experiment was carried out in FRBD and replicated thrice. Treatment comprising two factors as follows.

\section{Factor I: Method of crop establishment}

$\mathrm{E}_{1}-$ Line sowing with $25 \times 10 \mathrm{~cm}$

$\mathrm{E}_{2}$ - Line sowing with $35 \times 10 \mathrm{~cm}$

$\mathrm{E}_{3}-$ Transplanting with $25 \mathrm{x} 10 \mathrm{~cm}$

$\mathrm{E}_{4}-$ Transplanting with $35 \times 10 \mathrm{~cm}$

\section{Factor II: Nutrient management}

$\mathrm{N}_{1}-75 \%$ Recommended dose of fertilizer

$\mathrm{N}_{2}-100 \%$ Recommended dose of fertilizer *

$\mathrm{N}_{3}-125 \%$ Recommended dose of fertilizer

*Recommended Dose - Nitrogen $44 \mathrm{Kg} / \mathrm{ha}$ and Phosphorous $22 \mathrm{~kg} / \mathrm{ha}$

Kudiraivali variety Co (KV) 2 comes to harvest at 90 days. Totally twelve treatment combinations were tried. Biometric observations were recorded at various growth stages. At establishment stage plant population $/ \mathrm{m}^{2}$ was taken.

The growth parameters like plant height and number of tillers were recorded. At harvest stage the yield attributes viz., number of panicles/hill, length of the panicle and grain yield were recorded. All the collected datas were statistically analyzed.

\section{Results and Discussion}

The effect of different methods of crop establishment and nutrient management practices on growth parameters and yield attributes are presented in Table 1 and 2, respectively. The results revealed that transplanting at $35 \times 10 \mathrm{~cm}$ with $125 \% \mathrm{RDF}$ $\left(\mathrm{E}_{4} \mathrm{~N}_{3}\right)$ recorded the highest plant population and showed significant differences with other treatment combinations. Similarly the same treatment combination $\left(\mathrm{E}_{4} \mathrm{~N}_{3}\right)$ recorded the highest plant height and more number of tillers per hill. However, there is no significant difference in the growth parameters viz., plant height and number of tillers. 
Table.1 Effect of crop establishment techniques and nutrient management growth parameters

\begin{tabular}{|c|c|c|c|}
\hline Treatment & $\begin{array}{l}\text { Plant population per } \\
\text { quadrate }\left(0.25 \mathrm{~m}^{2}\right)\end{array}$ & $\begin{array}{l}\text { Plant height } \\
\text { (Cm) }\end{array}$ & $\begin{array}{l}\text { No. of tillers per } \\
\text { hill }\end{array}$ \\
\hline \multicolumn{4}{|c|}{ Factor - 1: Method of crop establishment } \\
\hline $\mathbf{E}_{1}$ & 6.32 & 137.8 & 3.68 \\
\hline$\overline{E_{2}}$ & 7.11 & 145.2 & 5.11 \\
\hline $\mathbf{E}_{3}$ & 7.64 & 153.9 & 6.23 \\
\hline $\mathbf{E}_{4}$ & 8.15 & 162.5 & 6.96 \\
\hline SED & 0.22 & 10.23 & 0.70 \\
\hline CD (0.05) & 0.43 & 20.41 & 0.15 \\
\hline \multicolumn{4}{|c|}{ Factor - 2 : Nutrient management } \\
\hline N1 & 6.18 & 142.4 & 5.29 \\
\hline $\mathbf{N 2}$ & 7.27 & 153.6 & 5.49 \\
\hline N3 & 7.81 & 165.8 & 5.71 \\
\hline SED & 0.16 & 9.82 & 0.06 \\
\hline $\mathrm{CD}(0.05)$ & 0.34 & 19.1 & 0.03 \\
\hline \multicolumn{4}{|l|}{ Interaction } \\
\hline $\mathbf{E}_{1} \mathbf{N}_{1}$ & 6.17 & 142.3 & 3.30 \\
\hline $\mathbf{E}_{1} \mathbf{N}_{2}$ & 6.29 & 146.5 & 3.70 \\
\hline $\mathbf{E}_{1} \mathbf{N}_{3}$ & 6.76 & 150.6 & 4.03 \\
\hline $\mathrm{E}_{2} \mathbf{N}_{1}$ & 7.08 & 154.2 & 4.97 \\
\hline $\mathbf{E}_{2} \mathbf{N}_{2}$ & 7.29 & 157.3 & 5.12 \\
\hline $\mathrm{E}_{\mathbf{3}} \mathbf{N}_{3}$ & 7.89 & 161.4 & 5.24 \\
\hline$\overline{\mathbf{E}_{3} \mathbf{N}_{1}}$ & 7.88 & 162.5 & 6.08 \\
\hline $\mathbf{E}_{3} \mathbf{N}_{2}$ & 8.23 & 169.7 & 6.18 \\
\hline $\mathbf{E}_{3} \mathbf{N}_{3}$ & 7.88 & 173.2 & 6.43 \\
\hline $\mathbf{E}_{4} \mathbf{N}_{1}$ & 8.23 & 165.4 & 6.80 \\
\hline $\mathbf{E}_{4} \mathbf{N}_{2}$ & 8.60 & 169.7 & 6.97 \\
\hline $\mathbf{E}_{4} \mathbf{N}_{3}$ & 8.69 & 171.3 & 7.12 \\
\hline SED & 0.18 & 10.14 & 0.12 \\
\hline CD (0.05) & 0.37 & 21.02 & NS \\
\hline
\end{tabular}


Table.2 Effect on yield and yield attributes of barnyard millet under sodic soil condition

\begin{tabular}{|c|c|c|c|}
\hline Treatment & $\begin{array}{c}\text { Number of panicles } \\
\text { per hill }\end{array}$ & $\begin{array}{l}\text { Panicle length } \\
(\mathrm{Cm})\end{array}$ & $\begin{array}{l}\text { Grain Yield } \\
\text { (Kg/ha) }\end{array}$ \\
\hline \multicolumn{4}{|c|}{ Factor -1 : Method of crop establishment } \\
\hline $\mathbf{E}_{1}$ & 3.55 & 21.61 & 736 \\
\hline $\mathbf{E}_{2}$ & 3.63 & 21.50 & 783 \\
\hline $\mathbf{E}_{3}$ & 4.20 & 22.26 & 873 \\
\hline $\mathbf{E}_{4}$ & 5.83 & 20.33 & 917 \\
\hline SED & 0.06 & 0.17 & 12.24 \\
\hline $\mathrm{CD}(\mathbf{0 . 0 5})$ & 0.12 & 0.35 & 25.38 \\
\hline \multicolumn{4}{|c|}{ Factor - 2 : Nutrient management } \\
\hline N1 & 3.37 & 20.30 & 793 \\
\hline $\mathbf{N 2}$ & 4.38 & 21.61 & 825 \\
\hline $\mathbf{N 3}$ & 5.16 & 22.38 & 864 \\
\hline SED & 0.05 & 0.15 & 10.60 \\
\hline CD (0.05) & 0.11 & 0.30 & 22.00 \\
\hline \multicolumn{4}{|c|}{ Interaction (E x N) } \\
\hline $\mathbf{E}_{1} \mathbf{N}_{1}$ & 3.00 & 20.44 & 698 \\
\hline $\mathbf{E}_{1} \mathbf{N}_{2}$ & 3.60 & 22.08 & 736 \\
\hline $\mathbf{E}_{1} \mathbf{N}_{3}$ & 4.04 & 22.30 & 781 \\
\hline $\mathbf{E}_{2} \mathbf{N}_{1}$ & 3.30 & 20.74 & 740 \\
\hline $\mathbf{E}_{2} \mathbf{N}_{2}$ & 3.60 & 21.86 & 790 \\
\hline $\mathbf{E}_{2} \mathbf{N}_{3}$ & 4.00 & 21.90 & 838 \\
\hline $\mathbf{E}_{3} \mathbf{N}_{1}$ & 3.60 & 21.28 & 849 \\
\hline $\mathbf{E}_{3} \mathbf{N}_{2}$ & 4.00 & 21.90 & 898 \\
\hline $\mathbf{E}_{3} \mathbf{N}_{3}$ & 5.00 & 23.60 & 946 \\
\hline $\mathbf{E}_{4} \mathbf{N}_{1}$ & 3.60 & 18.70 & 905 \\
\hline $\mathbf{E}_{4} \mathbf{N}_{2}$ & 6.30 & 20.60 & 951 \\
\hline $\mathbf{E}_{4} \mathbf{N}_{3}$ & 7.60 & 21.70 & 997 \\
\hline SED & 0.10 & 0.29 & 21.20 \\
\hline CD (0.05) & 0.22 & 0.61 & 43.00 \\
\hline
\end{tabular}

The increase in all growth parameters may be due to reduced plant population per unit area due to wider spacing which resulted in lesser competition among the plants and also more photosynthesis activity as a result of better solar light inception on the leaves and also proper utilization of water and nutrients in a critical crop growth period. These findings are supported by the findings of Avasthe et al., (2012) where in rice lesser number of tillers and panicles per hill were recorded at closer spacing while wider spacing recorded higher number of tillers and panicles

Regarding the yield attributing characters transplanting at $35 \times 10 \mathrm{~cm}$ with $125 \%$ RDF $\left(\mathrm{E}_{4} \mathrm{~N}_{3}\right)$ recorded more number of panicles per hill (7.60) and panicle length (23.60). It is found that there is a significant difference between the treatments in number of panicles and panicle length. This might be due to more population of plants by close spacing and 
hence more yield per hectare. Highest grain yield of $997 \mathrm{Kg} / \mathrm{ha}$ was recorded in the treatment combination of transplanting at $35 \mathrm{x}$ $10 \mathrm{~cm}$ with $125 \% \operatorname{RDF}\left(\mathrm{E}_{4} \mathrm{~N}_{3}\right)$. This is followed by the treatment transplanting at 25 $x 10 \mathrm{~cm}$ with $125 \% \operatorname{RDF}\left(\mathrm{E}_{4} \mathrm{~N}_{2}\right)$. Line sowing at at $25 \times 10 \mathrm{~cm}$ with $75 \% \mathrm{RDF}$ recorded the lowest grain yield of $708 \mathrm{Kg} / \mathrm{ha}$. This is mainly due to adequate spacing plant can gain sufficient sunlight, water and nutrition from soil, which can influence healthy yield and yield attributes.Khan and Agrawal (1995) reported in ragi that the seed yield was highest with $2,60,000$ plants per hectare compared to reduced populations than this.

From this study, it is concluded that transplanting at $35 \times 10 \mathrm{~cm}$ with $125 \% \mathrm{RDF}$ $\left(\mathrm{E}_{4} \mathrm{~N}_{3}\right)$ could be adopted to get higher grain yield in barnyard millet under sodic soil condition.

\section{References}

Avasthe, R. K., Verma, S., Ashok Kumar and Rahman, H., 2012, Performance of rice (Oryza sativa) varieties at different spacing under system of rice intensification (SRI) mid hill acid soils of Sikkim Himalaya, Indian J. Agric., 79(1): 32-37.

Khan, I. M. and Agrawal, V. K., 1995, Seed yield in finger millet cultivars as influenced by plant density and nitrogen levels. JNKVV Res. J., 27(1): 25-27.

Sahu, B. N., 1965, Response of different crops to fertilizer application in different soils. J. Indian Soc. Soil Sci., 13: 241-249.

\section{How to cite this article:}

Anandha Krishnaveni, S. 2018. Effect of Method of Crop Establishment and Nutrient Management in Barnyard Millet under Sodic Soil Condition. Int.J.Curr.Microbiol.App.Sci. 7(12): 51-55. doi: https://doi.org/10.20546/ijcmas.2018.712.007 